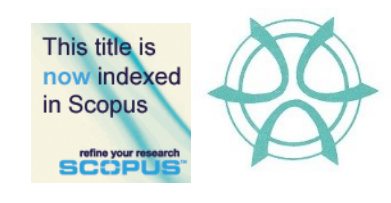

\title{
PARTICIPATION IN E-GOVERNMENT SERVICES AND SMART CITY PROGRAMS: A CASE STUDY OF MALAYSIAN LOCAL AUTHORITY
}

\author{
Lim Seng Boon ${ }^{1}$, Jalaluddin Abdul Malek², Mohd Yusof Hussain², \\ \& Zurinah Tahir ${ }^{4}$ \\ ${ }^{1,2,3,4}$ School of Social, Development and Environmental Studies \\ Faculty of Social Sciences and Humanities \\ UNIVERSITI KEBANGSAAN MALAYSIA
}

\begin{abstract}
Public participation is gaining popularity in local governance practices where the involvement of the public in the decision-making process is essential in promoting good governance concepts. However, local authorities are facing challenges in guiding public involvement in e-government services such as smart city programmes. Hence, this paper aimed to examine the participation process in e-government services and smart city programmes, and later to recommend a framework to assess participation level and process in local context. Petaling Jaya, Malaysia, was selected as a case study where interviews and observations were conducted with thematic analysis based on relevant themes. Through the selected attributes and designated questions in the participation framework, time and effort can be saved in addition to clearing the ambiguities of stakeholders who are keen on gaining the authentic participation culture in e-services and smart city programmes. This study has provided new insights on how egovernment can be implemented by the local government after adopting a smart city policy in the context of public participation.
\end{abstract}

Keywords: Authentic participation, citizens as equal partners, citizens' prerequisite of participation, public engagement, smart cities, transparency governance

\footnotetext{
${ }^{1}$ PhD Candidate at Universiti Kebangsaan Malaysia. Email: limsengboonn@gmail.com
} 


\section{INTRODUCTION}

Due to the advent and advancement of Information and Communication Technology (ICT), e-government has been practiced since the early 1990s. The initial idea of e-government is to digitize manual paperwork and information of municipalities before publishing this information online through web portals (Yildiz, 2007). The e-government idea is considered as one of the Information System (IS) applications in easing governance. The research on the importance of user participation was pioneered by Mumford (1979) in order to develop the design and implement computer-based IS. Attention from scholars such as Cavaye (1995), DeLone and McLean (2003), and Lynch and Gregor (2004) have revealed the significance of user participation in constructing a successful IS. Furthermore, recent e-governance research such Axelsson and Melin (2008), Axelsson et al. (2010), Jafari and Ali (2011), Kamalia Azma and Nor Laila (2017) have linked the concept of IS to e-government with empirical evidence.

Accordingly, the term 'user' participation is used interchangeably with 'citizen' participation when the government deals directly with citizens in its governing area (Axelsson \& Melin, 2008). In another stream of development, the physical governing area of e-government mostly encompasses the city, and the smart city development has attracted growing attention in the 21st century; approximately a decade after the propagation of e-government (Anthopoulos \& Fitsilis, 2013). Giffinger et al. (2007) have proposed six elements that construct the smart city conception, namely smart governance, economy, people, environment, living, and mobility. Other scholars, such as Alonso and Castro (2016) as well as Nam and Pardo (2011), have also highlighted the aspect of governance as the backdrop of smart city development. As such, the type of governance employed in a smart city inclines towards participatory, where the involvement of citizens in decision making is emphasized, alongside co-creating, or co-producing with citizens in city services (Giffinger et al., 2007).

It is evident that the linking of user participation in e-government services (or e-services) with citizen participation in a smart city is an emerging phenomenon (Anthopoulos \& Fitsilis, 2013). However, this area is still lacking in empirical evidence, especially in Malaysian local context. Axelsson and Melin (2008) claimed that participation in e-government context can be understood from user participation in the Information System (IS) discipline. Nonetheless, most of the local authorities have adopted smart city policy and changes are inevitable in the implementation of the e-government. It is discovered that the participation framework proposed by Axelsson and Melin (2008) was lacking in terms of experiences from citizen participation in smart city programmes. Thus, the current paper aims to examine both the public participation in e-services and smart city programmes in the City Council of Petaling Jaya, Malaysia, as well as to suggest a framework for assessing participation in local context. 
Lim Seng Boon, Jalaluddin Abdul Malek, Mohd Yusof Hussain \& Zurinah Tahir

Participation in E-Government Services and Smart City Programs: A Case Study of Malaysian Local Authority

The following section discusses the existing literature of the attributes of participation which can be transformed into a set of questions that highlights the citizens' perspective. Furthermore, the difference between the focus of the value chain of public services in user or citizen participation is also addressed. Then, the case study is explained, followed by the evaluation of interview themes results, suggestions and conclusion.

\section{ATTRIBUTES OF PARTICIPATION}

The participation topic can be evaluated based on three major disciplines namely, IS (i.e. Mumford, 1979), development and planning (i.e. Arnstein, 1969), or public administration and management discipline (i.e. Vigoda, 2002). With regard to linking the user to the citizen participation concept, this study will specifically emphasise on the perspective of IS discipline with complementary opinions from other disciplines.

According to Mumford (1979), there are three types of user participation which are consultative, representative, and consensus. This conception states that the main concern of user participation is the influence on decision making in the design and implementation stages of a computer-based IS. Based on Mumford's theory, Cavaye (1995) has categorised the characteristics of user participation into six attributes, namely type, degree, content, extent, formality, and influence of participation. Cavaye's attributes has been further expanded by Lynch and Gregor (2004) and Axelsson and Melin (2008). In developing Cavaye's framework, the attribute of the depth of participation has been added by Lynch \& Gregor in their work. Additionally, there are three conditions that have been forwarded, namely, 1) the stages of involvement (in the authors' view, this factor overlaps with the extent of participation in Cavaye), 2) frequency of interactions (how active they are), and 3) voices from users (to influence the decision making, similar to Munford and Cavaye's theories). Furthermore, due to the importance of measuring the practical impact of participation activity, Axelsson and Melin (2008) have added an attribute on the (practical) result of participation in their findings.

On the other hand, in the DeLone and McLean (2003) IS success model, they have reconceptualised user participation within the scopes of 1) intention to use and 2) use, based on DeLone and McLean (1992) model. While the term 'intention to use' refers to the interest to pursue, 'use' can be defined as the action to adopt. It should be emphasised that programmes in a smart city cannot be executed successfully without these two factors of citizen involvement. Thus, it is argued that these two attributes are the "citizens' prerequisites" for the authorities in ensuring the effectiveness of the e-services and smart city programmes. This citizens' prerequisite attribute is different from the prerequisites on officials' administrative experience as proposed by Axelsson et al. (2010)'s and it is viewed from the demand side of citizens. 


\section{THE VALUE CHAIN OF PARTICIPATION}

It is observed that the topic of user participation is focused on the process of 'design', 'testing', or 'implementation' of a computer system and that it does not encompass another value chain. For example, in the bigger scope of the value chain of a programme, or activity organised by a municipality, the processes typically involve 1) agenda setting, 2) decision making, 3) planning, 4) design and testing, 5) commissioning, 6) managing, 7) implementation (vast involvement of users), 8) controlling, and 9) evaluation (Bovaird, 2007). These stages are significant to expand beyond the only focus on the middle stages of design and implementation, to the wider scope of the whole value chain of municipality's services, i.e. the scale of city services level that could also involve the whole city populations. It is much more complex than the internal computerbased IS services level where the emphasis is typically given to a rather welldefined group/users, for instance, in an enterprise resource planning system situation dedicated to a certain industry or market segment (Axelsson et al., 2010).

Although the expansion for deeper engagement is advantageous, Irvin and Stansbury (2004) have described certain conditions under which citizen participation may be costly and ineffective to both government and citizens. Thus, it is implied that all participation activities must be carefully monitored and appropriated to the community's particular needs and interests (Cornwall, 2008). According to White (1996), the interests of 'who' participates range from the perspective of 'top-down': the interests of those who decide, design, and implement development programmes have in the participation of others, as well as 'bottom-up': how the participants perceive their participation, and what they expect to gain out of it. It is discovered that the 'interest' described by White and Cornwall is akin to the 'intention to use' proposed by Delone and McLean (2003), and the 'desired level' by Howcroft and Wilson (2003), where the interest of action will not occur without intention and desire in mind.

Based on the discussion of the literature above, a conceptual framework (refer Table 1) is proposed to offer a better understanding of participation in eservices and smart city programmes.

Table 1 Conceptual framework for assessing citizen participation in e-services and smart cities

\begin{tabular}{lll}
\hline \multicolumn{1}{c}{ Discipline } & \multicolumn{1}{c}{ Scholar } & \multicolumn{1}{c}{ Attributes of Participation } \\
\hline UP-IS & Cavaye's (1995) six attributes & $\begin{array}{l}\text { Type, Degree, Content, Extent, Formality and } \\
\text { Influence }\end{array}$ \\
\hline UP-IS & Lynch and Gregor (2004) & Depth \\
\hline CP-eGov & Axelsson and Melin (2008) & Result \\
\hline CP-SC & The authors & Citizens' prerequisite \\
\hline $\begin{array}{l}\text { Note: UP represents user participation; IS represents information systems; CP represents citizen } \\
\text { participation; eGov represents electronic government; SC represents the smart city. } \\
\end{array}$ & Source: The authors (2019)
\end{tabular}


Lim Seng Boon, Jalaluddin Abdul Malek, Mohd Yusof Hussain \& Zurinah Tahir

Participation in E-Government Services and Smart City Programs: A Case Study of Malaysian Local Authority

\section{METHODOLOGY}

A case study approach (Yin, 2018) has been employed in this study. Interviews and observations on the authority's websites were the primary methods utilised. The interviews were conducted using semi-structured questions that were formulated based on the attributes of participation discussed in the literature. Using purposive sampling, 12 interviews were carried out with the city stakeholders of the Petaling Jaya (PJ) city, Malaysia (refer Table 2). Codes were extracted from interview transcripts, in addition to themes for thematic analysis using Atlas.ti. The interviews and transcriptions were carried out by the first author, while codes and themes were triangulated by the other three authors.

Table 2 The informants in this study

\begin{tabular}{lc}
\hline \multicolumn{1}{c}{ Informants (abridgement) } & Quantity \\
\hline Politicians (include councillors) (PC) & 3 \\
\hline Officers (O) & 3 \\
\hline Corporate Sectors (CS) & 2 \\
\hline Academics (A) & 1 \\
\hline $\begin{array}{l}\text { Community leaders and representatives from } \\
\text { NGOs (C) }\end{array}$ & 3 \\
\hline Total & 12 \\
\hline
\end{tabular}

Observations were conducted towards the selected 14 e-services (websites) of the City Council of Petaling Jaya (MBPJ) and was evaluated within the period of July to December 2018. The observation was conducted on the aspects of functionality, accessibility, and maintenance status.

\section{The Case Study of Petaling Jaya, Malaysia}

The real-life setting of the PJ city, was chosen due to its prominent recognition as a successful pioneer in implementing the Local Agenda 21 among municipalities in Malaysia. Its vision towards becoming a smart and sustainable city with an emphasis on community participation in governance (MBPJ, 2012) has also become the deciding factor in its selection as the case study.

The e-government service elements in the MBPJ include the official websites and other related links, Facebook pages, e-kiosk for fiscal payment, complaint applications, and email accounts among others. This study focuses on websites with regard to the e-service subject. As for the smart city, it includes elements such as programmes, meetings, projects, and other citizen-related activities conducted by MBPJ. This study specifically considers the smart city subject in terms of programmes related to the smart city itself, and council meetings. 


\section{RESULTS AND DISCUSSIONS}

A total of 322 codes, 12 categories and 4 themes were categorized accordingly, whereby the 4 themes emerged in examining similarities and differences between experiences of e-government services and smart city programmes and meetings. They were: the ignored role of user/ citizen, the tokenism involvement in the value chain public services, the sense of belonging decides the sustainability of services, and the prerequisite of organising ability, knowledge, and volunteering spirit.

\section{The Ignored Role and Trust of User/ Citizen}

In e-government services, majority of the informants (i.e. PC1, PC3, O1, O2, O3, $\mathrm{A} 1, \mathrm{C} 2$, and $\mathrm{C} 3$ ) comprehended that the users' role is direct and simple, i.e. to use the services according to the rules set by the service provider, MBPJ. Nonetheless, the quality of the service provider is observed to still be at the infancy stage (i.e. A1, C1, P1, P2, and PC2). In contrast, the community leader informants $\mathrm{C} 2$ and $\mathrm{C} 3$ commented that citizens' role in smart city council meetings is mostly indirect and through representatives, where they are not allowed to attend or vote in the decision-making meetings. In smart city programmes, the role of citizens is most direct but limited on the implementation stage and they can only join as participants (i.e. PC3 and C1). This situation implies that the type of consensus of all users involved in consultation as highlighted by Mumford (1979) does not happen in both cases of e-services and smart city meetings and programmes.

This study focuses on the municipal website e-services where they act as an alternative for users to communicate online, rather than be physically present at the municipal's offices. These e-services will benefit users who wish to pay fiscal bills, license or compounds, lodge and check complaints, check services or rent community facilities, check job vacancies, download forms, check tender and status contractor, as well as those who want to register as PJ Green Squad membership (MBPJ, 2019). The official portal (http://www.mbpj.gov.my/en/rakyat/e-services) serves as the master portal for the individual links alongside other existing domains which include embpj.mbpj.gov.my (new), eps.mbpj.gov.my, and eperkhidmatan.mbpj.gov.my. It is commented by the corporate informant CS2 and citizen informant $\mathrm{C} 1$ that some old MBPJ websites, such as eAduan, a compound checking website, is not mobile-responsive and not directly linked to the android applications, namely Smart Selangor Parking, eLesen MBPJ, SmartPJenforcement, mForm MBPJ, PJ City Bus, and PJ Sustainable Community Award.

With regard to smart city, the officer informants $\mathrm{O} 1$ and $\mathrm{O} 2$ explained that MBPJ is in the process of building a comprehensive dashboard for the smart city under the Planning Department. One of the interfaces launched in the Smart 
Lim Seng Boon, Jalaluddin Abdul Malek, Mohd Yusof Hussain \& Zurinah Tahir

Participation in E-Government Services and Smart City Programs: A Case Study of Malaysian Local Authority

Selangor Conference on September 2018 is the community dashboard (https://pjkcd.net). This dashboard is used for engaging citizens, as well as registering volunteers. According to an officer informant O3, MBPJ currently targets to collect a body of data consisting of 20,000 volunteers in the year 2025 . Nevertheless, one of the community leader informants C 3 expressed uneasiness while using the community dashboard and other MBPJ websites. Informant C3 reported that these websites are mostly not user-friendly, and not completely constructed. These difficulties have consequently resulted in lack of trust toward the e-system.

\section{The Tokenism Involvement in the Value Chain Public Services}

According to officer informants $\mathrm{O} 1$ and $\mathrm{O} 2$, in the MBPJ e-government services, users are subject to implementation, not of design where they tend to be programmed to involve in the lower level in the value chain. Meanwhile, politician informant PC3 felt that the spectrum of the value chain that can cater to citizens' involvement in the smart city is much wider, but limited in practices.

As for the former, community leader informants $\mathrm{C} 2$ and $\mathrm{C} 3$ mentioned that users were asked to join passively as 'novice' who are subject to the rules and setting in the information system, i.e. pay bills, create inquiry in the websites with a lack of opportunities for innovative discussions. The participation is limited as they are not directly involved in the other stages such as agenda-setting, planning, design, or evaluation. Thus, the focus on the lower stage of value chain resembles Arnstein's (1969) informing or manipulating level. Notwithstanding these limitations, this situation has been accepted internally as the concern of the municipal is legitimising its administration (i.e. O1, $\mathrm{O} 2$ and $\mathrm{PC} 1$ ).

As for the later, according to politician $\mathrm{PC} 3$ and community leader $\mathrm{C} 3$, citizens were advised to direct their concerns, opinions or complaints through their representatives; this process is subject to discussions and decisions made in meetings. The final decision is in the power of the mayor and 24 councillors, and citizens have no voting power over local issues. Even though the technical departments attend the meetings, they are only there to provide technical advice. A councillor $\mathrm{PC} 2$ and an officer $\mathrm{O} 2$ claimed that the decision-making process that takes place in the meeting should only be attended by councillors and that the involvement of all citizens will be chaotic as it is much harder to vote, impractical and described as a waste of time and effort. These opinions are considered as the cost of participation explained by Irvin and Stansbury (2004).

\section{The Sense of Belonging in Participation}

In e-government services, the depth of participation was based on the context of demand, follow-up, and time constraint. For example, according to NGO informant C1, both websites of PJ Youth Information System and platform to advertise preloved items have ceased in action as they have been idle with no 
updates for a long time. Corporate informants CS1 and CS2 pointed out that these are the typical examples of lack of demand, a follow-up from the officers, change of top-down policy, or time constraint where other programmes have been prioritised. According to the academician A1 and corporate informants CS1 and $\mathrm{CS} 2$, these scenarios of website abandonment frequently happen and the society at large has been indifferent i.e. 'numb' about it. The academic informant A1 further added that the citizens have no power over these idle programmes as they are in a subjugated position, resulting in a low sense of belonging.

Contrastingly, community leader $\mathrm{C} 3$ mentioned that physical contact occurred in smart city participation where citizens' sense of belonging could last longer and produce a stronger impact. Some projects have been actively involving local communities where they depend on the level of power delegated and support of financial assistance. For instance, officers $\mathrm{O} 1$ and $\mathrm{O} 2$ explained that the PJ community award has been a success where communities were given the opportunities to compete and showcase their innovative ideas to win grants in monetary term. The winning team became models for others to produce a sustainable community, including programmes such as urban farming, tackling cleanliness, and fighting against dengue. Officers, NGOs and citizen informants (i.e. O1, O2, C1, C2 and C3) have acknowledged the positive impact of this programme, as it creates time for bonding between neighbours and community, reduces the risk of pollution, and saves expenses in urban management. A new version of award - PJ SEED community grant programme with a total of RM 3 million has been launched in March 2019 (Sakdon, 2019). In this case, the authenticity of participation as conceptualised by King et al. (1998) is achieved when the interaction style is of collaborative where citizens are treated as 'equal partner'.

\section{The Prerequisite of Organising Ability, Knowledge, and Volunteering Spirit}

Officers $\mathrm{O} 2$ and $\mathrm{O} 3$ clarified that the influence of user participation in PJ depends on the level of usage, the number of visitors, the number of complaints received on such e-service platforms. There is no organising action from users involved; most cases in e-services involve individual users. Nonetheless, corporate informant CS1 sensed that treating users as mere customers has created neverending demands in e-services. Under such circumstances, the supply side of the administrator acted as managers under the responsive type of interaction (Vigoda, 2002). The administrator prepared a set of customer feedback surveys to gain knowledge from the demand side. However, based on officers $\mathrm{O} 1$ and O3, that most of the improvement of the e-services were based on internal officers' guesses, where guesses made based on experiences correlate with Axelsson and Melin's (2008) finding. 
Lim Seng Boon, Jalaluddin Abdul Malek, Mohd Yusof Hussain \& Zurinah Tahir

Participation in E-Government Services and Smart City Programs: A Case Study of Malaysian Local Authority

In ensuring the success of smart city programmes that directly address the citizens' interest on wellbeing, councillors PC1 and PC2 suggested citizens should organise the programmes themselves by voicing out their opinions collectively, as well as signing petition or memorandum. Otherwise, the minority or single voices will be subjugated (Olson, 2002). Nonetheless, it has been observed that most citizens were self-centred, and did not oblige to actively organise the programmes on their own.

In addition to use and intention to use (interest), another code that 'knowledge' is important in using e-services was discovered. The term 'knowledge' refers to the basic ICT knowledge such as user login, password security, personal emails, and searching for relevant information on websites. Furthermore, when users have strong knowledge in ICT, they will be more cautious about the privacy of data which are shared online through these e-service platforms. In the case of a smart city, professional expertise such as engineering, urban planning or law are vital during the process of drafting appeals to the authority. The content of the appeal which represents the voices of affected citizens is crucial when councillors bring these reports into meetings.

Another code that has been identified is the volunteering spirit. For example, there were social entrepreneur informants who have been working on a website or applications that can help those in need. These informants are representatives from the Epic Homes, and Eijau Millennium Explorer, and both of them have been active in community work and in accumulating volunteers to take part in community projects such as the Kampung Lindungan Community library project (Ch'ng, 2018). Despite this example of active involvement, the volunteering works at the grassroots level are actually very minimal compared to the large population of 730,000 in Petaling Jaya (MBPJ, 2018).

Hence, in addition to use and intention to use, other new codes for the prerequisites of participation have been discovered, namely the organising ability, knowledge, and volunteering spirit.

\section{SUGGESTIONS AND CONCLUSION}

From the above discussed themes, the local framework was proposed with an addition of a new attribute of citizens' prerequisites for participation in local context (refer Table 3 below). Through the 9 attributes, 12 designated questions and experiences stated in the Table 3 below; effort can be saved, as well as eliminating the ambiguities of stakeholders who are keen on gaining the authentic participation in e-services, smart city programmes. It should be highlighted that the culture of authentic participation process in Malaysia will hardly occur without such citizens' prerequisites which later result in tokenism participation (Mariana, 2008) and loosening of the public trust on the grassroots level (Zikri et al., 2015). 
Besides these suggestions, it must be noted that this study has few limitations, such that it only focused on the municipality's websites, while in fact, the e-services included other platforms such as social media, e-payment kiosk machines, and email. It should also be noted that smart city participation encompasses aspects beyond the domain of programmes. Thus, researchers are urged to test the constructed framework and explore comprehensively in comparing the two. Furthermore, other quantitative methodologies, mixedmethod, or multiple case studies across countries are recommended in further triangulating the results of the framework.

Table 3 A local framework for assessing participation in e-services and smart cities

\begin{tabular}{|c|c|c|c|}
\hline $\begin{array}{c}\text { Participation } \\
\text { attributes }\end{array}$ & $\begin{array}{l}\text { Citizens' } \\
\text { perspective } \\
\text { questions }\end{array}$ & $\begin{array}{c}\text { Experiences in e- } \\
\text { services (i.e. websites) }\end{array}$ & $\begin{array}{l}\text { Experiences in smart cities } \\
\text { (i.e. programmes) }\end{array}$ \\
\hline $\begin{array}{l}\text { 1) Citizens' } \\
\text { prerequisite } \\
\text { of } \\
\text { participation }\end{array}$ & $\begin{array}{l}\text { What are the } \\
\text { prerequisites of } \\
\text { participating } \\
\text { citizens? }\end{array}$ & $\begin{array}{l}\text { i) General knowledge to } \\
\text { use (i.e. go online), } \\
\text { ii) Intention to use } \\
\text { (interest to pursue), and } \\
\text { iii) Use (action to adopt) }\end{array}$ & $\begin{array}{l}\text { i) Professional knowledge (in } \\
\text { some cases, i.e. urban } \\
\text { planning), } \\
\text { ii) Volunteering spirit, } \\
\text { iii) Organising ability, } \\
\text { iv) Intention to use, and } \\
\text { v) Use }\end{array}$ \\
\hline \multirow[t]{2}{*}{$\begin{array}{l}\text { 2) Type of } \\
\text { participation }\end{array}$} & $\begin{array}{l}\text { Which citizens } \\
\text { participate in } \\
\text { development } \\
\text { activities? }\end{array}$ & $\begin{array}{l}\text { Users who have paid } \\
\text { bills, used book facilities, } \\
\text { as well as updated news } \\
\text { and activities in town. }\end{array}$ & $\begin{array}{l}\text { Citizens who were eager to } \\
\text { improve the quality of } \\
\text { services, the performance of } \\
\text { municipal, and the } \\
\text { democracy level in town. }\end{array}$ \\
\hline & $\begin{array}{l}\text { How is citizen } \\
\text { involvement } \\
\text { reached? }\end{array}$ & $\begin{array}{l}\text { Users were required to } \\
\text { log in to use the } \\
\text { information systems, but } \\
\text { most sites were free and } \\
\text { direct access were also } \\
\text { granted. }\end{array}$ & $\begin{array}{l}\text { Citizens were not invited in } \\
\text { meetings and decision- } \\
\text { making process; all stage was } \\
\text { conducted through } \\
\text { representatives i.e. } \\
\text { councillors. }\end{array}$ \\
\hline $\begin{array}{l}\text { 3) Degree of } \\
\text { participation }\end{array}$ & $\begin{array}{l}\text { What are the } \\
\text { citizens' } \\
\text { responsibilities? }\end{array}$ & $\begin{array}{l}\text { Users were not required } \\
\text { to/ or had less } \\
\text { responsibility towards the } \\
\text { e-services. } \\
\text { They would provide } \\
\text { unconscious data while } \\
\text { doing transaction/log in } \\
\text { e-services. }\end{array}$ & $\begin{array}{l}\text { Citizens had to share the } \\
\text { responsibility towards better } \\
\text { living in the city, thus, } \\
\text { assisting municipal in } \\
\text { decision making is crucial. } \\
\text { Nonetheless, since the } \\
\text { current democratic system } \\
\text { does not allow this, they can } \\
\text { only respond through } \\
\text { representatives and hope for } \\
\text { their voices to be heard in } \\
\text { meetings. }\end{array}$ \\
\hline $\begin{array}{l}\text { 4) Content of } \\
\text { participation }\end{array}$ & $\begin{array}{l}\text { What activities } \\
\text { are citizens } \\
\text { participating } \\
\text { in? }\end{array}$ & $\begin{array}{l}\text { According to the rules } \\
\text { and setting in the } \\
\text { information system, users } \\
\text { were asked to join }\end{array}$ & $\begin{array}{l}\text { Citizens were eligible to } \\
\text { participate in smart city- } \\
\text { related programmes, but not } \\
\text { in council and technical }\end{array}$ \\
\hline
\end{tabular}


Lim Seng Boon, Jalaluddin Abdul Malek, Mohd Yusof Hussain \& Zurinah Tahir

Participation in E-Government Services and Smart City Programs: A Case Study of Malaysian Local Authority

\begin{tabular}{|c|c|c|c|}
\hline & & $\begin{array}{l}\text { passively as 'novice'; } \\
\text { (e.g., to pay bills), lacking } \\
\text { rooms for innovative } \\
\text { discussions. }\end{array}$ & $\begin{array}{l}\text { meetings. However, they } \\
\text { were allowed to participate in } \\
\text { meetings once summoned by } \\
\text { the municipal or } \\
\text { representatives for internal } \\
\text { discussions. }\end{array}$ \\
\hline \multirow[t]{2}{*}{$\begin{array}{l}\text { 5) Extent of } \\
\text { participation }\end{array}$} & $\begin{array}{l}\text { In what stages } \\
\text { of development } \\
\text { do citizens } \\
\text { participate in? }\end{array}$ & $\begin{array}{l}\text { Users participated in the } \\
\text { implementation stage of } \\
\text { e-services, but not in the } \\
\text { design stage. }\end{array}$ & $\begin{array}{l}\text { Citizens were mostly } \\
\text { involved in the } \\
\text { implementation stages; } \\
\text { sometimes community } \\
\text { leaders might call them for } \\
\text { planning, design, evaluation } \\
\text { stages; but this condition } \\
\text { rarely happened in the } \\
\text { decision-making stage. }\end{array}$ \\
\hline & $\begin{array}{l}\text { To what extent } \\
\text { are citizens } \\
\text { involved } \\
\text { before, during } \\
\text { and after the } \\
\text { development } \\
\text { process? }\end{array}$ & $\begin{array}{l}\text { There was no } \\
\text { involvement before and } \\
\text { after stages. During the } \\
\text { usage stage, they acted as } \\
\text { passive users who } \\
\text { demanded user-friendly } \\
\text { e-services. }\end{array}$ & $\begin{array}{l}\text { The involvement was subject } \\
\text { to the municipal's } \\
\text { consideration. Citizens acted } \\
\text { as beneficiaries of } \\
\text { programmes. Situations in } \\
\text { which citizens were } \\
\text { delegated power as co- } \\
\text { producers were less common. }\end{array}$ \\
\hline $\begin{array}{l}\text { 6) Formality } \\
\text { of } \\
\text { participation }\end{array}$ & $\begin{array}{l}\text { How is citizen } \\
\text { participation } \\
\text { organised? }\end{array}$ & $\begin{array}{l}\text { No organising action } \\
\text { involved; mostly by } \\
\text { individual cases. }\end{array}$ & $\begin{array}{l}\text { It relied on interest; citizens } \\
\text { were sometimes organised } \\
\text { and spoke collectively. } \\
\text { Normally, citizens were not } \\
\text { obliged to organise actively } \\
\text { by themselves. }\end{array}$ \\
\hline $\begin{array}{l}\text { 7) Influence } \\
\text { of } \\
\text { participation }\end{array}$ & $\begin{array}{l}\text { What influence } \\
\text { do the } \\
\text { participating } \\
\text { citizens have on } \\
\text { the outcome? }\end{array}$ & $\begin{array}{l}\text { The higher level of usage, } \\
\text { an increasing number of } \\
\text { visitors, or fewer } \\
\text { complaints on such e- } \\
\text { services were considered } \\
\text { as a good sign. }\end{array}$ & $\begin{array}{l}\text { It relied on the organising } \\
\text { ability and knowledge in } \\
\text { order to present their ideas in } \\
\text { papers and meetings. Local } \\
\text { champions were needed for } \\
\text { higher influences, but all } \\
\text { were subjected to political } \\
\text { and government decisions. }\end{array}$ \\
\hline \multirow[t]{2}{*}{$\begin{array}{l}\text { 8) Depth of } \\
\text { participation }\end{array}$} & $\begin{array}{l}\text { How active are } \\
\text { citizens when } \\
\text { participating? }\end{array}$ & $\begin{array}{l}\text { Not active. The } \\
\text { participation of user were } \\
\text { based on needs, i.e. could } \\
\text { be once in a year in } \\
\text { paying bills. }\end{array}$ & $\begin{array}{l}\text { Not active in attending } \\
\text { meetings. However, for } \\
\text { programmes, the } \\
\text { participation relied on } \\
\text { interest matched. }\end{array}$ \\
\hline & $\begin{array}{l}\text { How deeply } \\
\text { involved are } \\
\text { citizens in the } \\
\text { development } \\
\text { project? }\end{array}$ & $\begin{array}{l}\text { Superficial involvement } \\
\text { while getting information } \\
\text { or e-services. Some } \\
\text { portals were idle due to } \\
\text { lack of demand, follow- } \\
\text { up and time constraint. }\end{array}$ & $\begin{array}{l}\text { The depth of participation } \\
\text { varied among citizens and } \\
\text { was influenced by physical } \\
\text { contact and a sense of } \\
\text { belonging. }\end{array}$ \\
\hline $\begin{array}{l}\text { 9) Result of } \\
\text { participation }\end{array}$ & $\begin{array}{l}\text { What did the } \\
\text { citizen }\end{array}$ & $\begin{array}{l}\text { Achieved the information } \\
\text { or services demanded. }\end{array}$ & $\begin{array}{l}\text { Achieved the aim of a better } \\
\text { living environment and } \\
\text { community, as well as }\end{array}$ \\
\hline
\end{tabular}


PLANNING MALAYSIA

Journal of the Malaysia Institute of Planners (2020)

\begin{tabular}{ll}
\hline $\begin{array}{l}\text { participation } \\
\text { result in? }\end{array}$ & $\begin{array}{l}\text { improving the internal } \\
\text { efficiency of the agency. }\end{array}$ \\
\hline
\end{tabular}

\section{ACKNOWLEDGEMENTS}

Source: The authors (2019)

This paper did not receive any specific grant from funding agencies in the public, commercial, or not-for-profit sectors.

\section{REFERENCES}

Alonso, R. G., \& Castro, S. L. (2016). Technology helps, people make: A smart city governance framework grounded in deliberative democracy. In J. Gil-Garcia (Ed.), Smarter as the New Urban Agenda (pp. 333-347). Cham Heidelberg: Springer.

Anthopoulos, L., \& Fitsilis, P. (2013). Evolution roadmaps for smart cities: Determining viable paths. Proceedings of the 13th European Conference of the E-Government, Varese, Italy, 13-14 June, 27-35.

Arnstein, S. R. (1969). A ladder of citizen participation. Journal of the American Institute of Planners, 35(4), 216-224.

Axelsson, K., \& Melin, U. (2008). Citizen participation and involvement in eGovernment projects: An emergent framework. In M. A. Wimmer, H. J. Scholl, \& E. Ferro (Eds.), EGOV 2008, LNCS 5184 (pp. 207-218). Verlag Berlin Heidelberg: Springer.

Axelsson, K., Melin, U., \& Lindgren, I. (2010). Exploring the importance of citizen participation and involvement in e-government projects. Transforming Government: People, Process and Policy, 4(4), 299-321.

Bovaird, T. (2007). Beyond engagement and participation: User and community coproduction of public services. Pub. Admin. Review, Sep-Oct, 846-860.

Cavaye, A. L. M. (1995). User participation in system development revisited. Information \& Management, 28, 311-323.

Ch'ng, B. (2018). New chapter opens for villagers in PJ. Retrieved March 16, 2019, from https://www.thestar.com.my/metro/metro-news/2018/08/04/new-chapter-opensfor-villagers-in-pj-unique-container-library-launched-to-enhance-education-inthe/

Cornwall, A. (2008). Unpacking "participation": Models, meanings and practices. Community Development Journal, 43(3), 269-283.

DeLone, W., \& McLean, E. (1992). Information Systems Success: The quest for the dependent variable. Information Systems Research, 3(1), 60-95.

DeLone, W., \& McLean, E. (2003). The DeLone and McLean model of information systems success: A ten-year update. Journal of Management Information Systems, 19(4), 9-30.

Giffinger, R., Fertner, C., Kramar, H., et. (2007). Smart cities: Ranking of European medium-sized cities. Wien: TU Vienna.

Irvin, R. A., \& Stansbury, J. (2004). Citizen participation in decision making. Pub. Admin. Review, 64(1), 55-65.

Jafari, S. M., \& Ali, N. A. (2011). Exploring the values of e-governance to citizens. ECASE \& e-Tech Inter. Conference, Jan'11, Tokyo, 1312-1332. 
Lim Seng Boon, Jalaluddin Abdul Malek, Mohd Yusof Hussain \& Zurinah Tahir

Participation in E-Government Services and Smart City Programs: A Case Study of Malaysian Local Authority

Kamalia Azma, K., \& Nor Laila, M. N. (2017). Citizen-centric demand model for transformational government systems. PACIS 2017 Proceedings. 139.

King, C. S., Feltey, K. M., \& Susel, B. O. (1998). The question of participation: Toward authentic public participation in public administration. Pub. Admin. Review, 58(4), 317-326.

Lynch, T., \& Gregor, S. (2004). User participation in decision support systems development. European Journal of Information Systems, 13, 286-301.

Majlis Bandaraya Petaling Jaya (MBPJ). (2012). Pelan Strategik Sustainable Petaling Jaya 2030. Petaling Jaya: Majlis Bandaraya Petaling Jaya.

Majlis Bandaraya Petaling Jaya (MBPJ). (2018). Petaling Jaya population demographics. Retrieved March 19, 2019, from https://www.pjkcd.net/population-demographics

Majlis Bandaraya Petaling Jaya (MBPJ). (2019). PJ Green Squad. Retrieved January 4, 2019, from http://eps.mbpj.gov.my/query/PJGreenSquadInfo.pdf

Mariana, M. O. (2008). Stakeholder participation in the implementation of Local Agenda 21 in Malaysia. PhD thesis, Universiti Putra Malaysia.

Mumford, E. (1979). Consensus systems design: An evaluation of this approach. In N. Szyperski \& E. Grochla (Eds.), Design and Implementation of CBIS. Groningen: Sijthoff and Noordhoff.

Nam, T., \& Pardo, T. (2011). Conceptualizing smart city with dimensions of technology, people \& institutions. Proceedings of the 12th Inter. Conf. on Dig. Gov. Research, June 12-15, College Park, MD, USA, 282-291.

Sakdon, Z. (2019). Council launches RM3mil community grant project. Retrieved March 10, 2019, from https://www.thestar.com.my/metro/metronews/2019/03/07/council-launches-rm3mil-community-grant-project/

Vigoda, E. (2002). From responsiveness to collaboration. Pub. Admin. Review, 62(5), 527-540.

White, S. C. (1996). Depoliticising development: The uses and abuses of participation. Development in Practice, 6(1), 6-15.

Yildiz, M. (2007). E-government research: Reviewing the literature, limitations, and ways forward. Government Information Quarterly, 24, 646-665.

Yin, R. K. (2018). Case Study Research and Applications: Design and Methods (Sixth Edition). Thousand Oaks: Sage.

Zikri, M., Tarmiji, M., \& Aziz, A. M. (2015). Local government service efficiency: Public participation matters. Int. Jour. of Soc. Science \& Humanity, 5(10), 827-831.

Received: January 2020. Accepted: $28^{\text {th }}$ May 2020 